\title{
Assessment of pruritus in patients with viral hepatitis B and $C$
}

\section{Ocena występowania świądu u pacjentów $z$ wirusowym zapaleniem wątroby typu B i C}

\author{
Anna Biernacka', Dawid Niżyński', Małgorzata Inglot² ${ }^{2}$ Adam Reich $^{3}$ \\ 'Department of Dermatology, Venereology and Allergology, Wroclaw Medical University, Poland \\ 2Department of Infectious Diseases, Hepatology and Acquired Immune Deficiencies, Wroclaw Medical University, Poland \\ ${ }^{3}$ Department of Dermatology, University of Rzeszow, Poland \\ 'Katedra i Klinika Dermatologii, Wenerologii i Alergologii Uniwersytetu Medycznego we Wrocławiu, Polska \\ ${ }^{2}$ Katedra i Klinika Chorób Zakaźnych, Chorób Wątroby i Nabytych Niedoborów Odpornościowych Uniwersytetu Medycznego \\ we Wrocławiu, Polska \\ 3Zakład Dermatologii Uniwersytetu Rzeszowskiego, Polska
}

Dermatol Rev/Przegl Dermatol 2018, 105, 264-272

DOI: https://doi.org/l0.51/4/dr.2018.75582

\author{
CORRESPONDING AUTHOR/ \\ ADRES DO KORESPONDENCJI: \\ prof. dr hab. Adam Reich \\ Zakład Dermatologii \\ Uniwersytet Rzeszowski \\ ul. Szopena 2 \\ 35-055 Rzeszów \\ tel.: +48 605076722 \\ e-mail: adi_medicalis@go2.pl
}

\begin{abstract}
Introduction. Itching is an unpleasant subjective sensation that leads to scratching. It is a common symptom of skin diseases but may also occur in various systemic diseases.
\end{abstract}

Objective. To assess the prevalence and clinical characteristics of itching accompanying viral hepatitis $\mathrm{B}(\mathrm{HBV})$ and/or $\mathrm{C}(\mathrm{HCV})$.

Material and methods. Screening was performed among 110 persons infected with HBV, HCV or both. A total of $22(20 \%)$ patients aged 2568 years with pruritus were included for further analysis. The study was based on a questionnaire containing questions about general health, duration of liver disease and its clinical picture, accompanying illnesses, medications and pruritus.

Results. In the analyzed group, 9 patients were diagnosed with type B hepatitis, whereas in 13 hepatitis type $C$ was confirmed. The duration of liver disease ranged from 3 to 22 years. In 15 (68.2\%) patients liver cirrhosis was documented; 1 (4.5\%) patient suffered from hepatocellular carcinoma. The most common site of pruritus was the trunk $(n=13$, $59.1 \%)$, generalized pruritus was observed in $3(13.6 \%)$ patients. Secondary scratch lesions were found in $14(63.6 \%)$ people. The most common period of pruritus occurrence was the evening and night, whereas pruritus was noted least commonly in the morning.

Conclusions. Pruritus affects about $20 \%$ of patients with viral hepatitis, which in some cases might be associated with marked liver damage or liver cirrhosis.

\section{STRESZCZENIE}

Wprowadzenie. Świąd jest nieprzyjemnym odczuciem wyzwalającym odruch drapania. Jest częstym objawem chorób skóry, ale może także wystąpić w różnych chorobach układowych.

Cel pracy. Zbadanie częstości występowania i obrazu klinicznego świądu u chorych z wirusowym zapaleniem wątroby (WZW) typu B i/lub C.

Materiał i metodyka. Wstępnej analizie poddano 110 osób zakażonych wirusami HBV i/lub HCV. Do dalszej oceny włączono 22 (20\%) pacjen- 
tów w wieku od 25 do 68 lat, u których stwierdzono świąd. Badanie oparto na ankiecie zawierającej pytania na temat ogólnego stanu zdrowia, czasu trwania choroby wątroby i jej objawów, chorób towarzyszących, stosowanych leków oraz świądu.

Wyniki. W analizowanej grupie WZW typu B zdiagnozowano u 9 pacjentów, natomiast WZW typu C u 13. Czas trwania choroby wątroby wynosił od 3 do 22 lat. U 15 (68,2\%) pacjentów rozpoznano marskość wątroby; $1(4,5 \%)$ uczestnik badania miał raka wątrobowokomórkowego. Najczęstszą lokalizacją świądu był tułów ( $n=13,59,1 \%)$, a uogólniony świąd obserwowano u $3(13,6 \%)$ chorych. Zmiany skórne wtórne do drapania odnotowano u 14 (63,6\%) pacjentów. Świąd najczęściej pojawiał się wieczorem oraz w nocy, najrzadziej w porze rannej.

Wnioski. Świąd występuje u około $20 \%$ chorych z WZW, przy czym przynajmniej w części przypadków może to być związane ze znacznym uszkodzeniem wątroby lub jej marskością.

Key words: hepatitis B virus, hepatitis C virus, itch, liver cirrhosis.

Słowa kluczowe: wirus zapalenia wątroby typu B, wirus zapalenia wątroby typu C, świąd, marskość wątroby.

\section{INTRODUCTION}

Pruritus is an unpleasant sensation which induces an urge to scratch or rub the skin [1]. This definition was proposed as early as 1660 by Hafenreffer and is still widely used. Pruritus is a type of exteroceptive sensation, different from pain, conducted to the central nervous system (CNS) via itch-specific afferent fibers (within C and A-delta fibers). It is a frequent symptom of many dermatoses, but may also be associated with various systemic diseases, such as chronic kidney insufficiency, hematological malignancies or endocrinological disorders [2]. Regarding liver function abnormalities, pruritus was described in the vast majority of patients suffering from primary biliary cirrhosis, significantly altering their quality of life $[2,3]$. Data on the prevalence of pruritus in subjects with other liver diseases including viral hepatitis are less numerous and less consistent $[4,5]$. Even more importantly, pruritus is repeatedly overlooked during the treatment of liver disease. However, pruritus, remarkably, is often more difficult to tolerate than pain [6].

\section{OBJECTIVE}

Therefore, we undertook a study to evaluate the prevalence and clinical manifestation of pruritus in patients with chronic viral hepatitis $B$ (hepatitis $B$ virus - $\mathrm{HBV}$ ) or $\mathrm{C}$ (hepatitis $\mathrm{C}$ virus - $\mathrm{HCV}$ ).

\section{MATERIAL AND METHODS}

Initially, we screened a total of 110 patients infected with $\mathrm{HBV}$ and/or HCV in order to

\section{WPROWADZENIE}

Świąd jest nieprzyjemnym odczuciem w obrębie skóry, które wywołuje potrzebę drapania lub pocierania [1]. Definicja ta została zaproponowana przez Hafenreffera w 1660 r. i jest powszechnie stosowana do dziś. W przeciwieństwie do bólu świąd należy do czucia eksteroceptywnego, w którym bodźce przewodzone są do ośrodkowego układu nerwowego (OUN) przez swoiste dla świądu włókna aferentne (w obrębie włókien typu C i A-delta). Świąd jest częstym objawem wielu chorób skóry, ale może także towarzyszyć schorzeniom układowym, takim jak przewlekła niewydolność nerek, nowotwory układu krwiotwórczego i choroby endokrynologiczne [2]. W przypadku zaburzenia czynności wątroby świąd opisywano u większości pacjentów z pierwotną marskością żółciową wątroby, u których istotnie wpływa on na jakość życia [2,3]. Dane dotyczące występowania świądu u pacjentów z innymi chorobami tego narządu, takimi jak wirusowe zapalenie wątroby (WZW), są mniej liczne, a także mniej spójne $[4,5]$. Co ważniejsze, świąd jest często pomijany w leczeniu schorzeń wątroby, mimo że chorzy niejednokrotnie uznają go za objaw bardziej uciążliwy niż ból [6].

\section{CEL PRACY}

Z tego względu podjęliśmy próbę oceny częstości występowania i obrazu klinicznego świądu u pacjentów z WZW typu B (hepatitis B virus - HBV) lub typu C (hepatitis C virus - HCV).

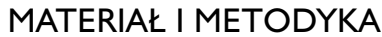

Wstępnej analizie poddano 110 osób zakażonych wirusem HBV i/lub HCV w celu identyfikacji pacjentów, 
identify subjects suffering from pruritus. Among them, $22(20 \%)$ patients (16 females $-72.7 \%$ and 6 males $-27.3 \%$; ratio: $2.7: 1$ ) aged between 25 to 68 years complained about itching and only these subjects were included in the final analysis. Detailed characteristics of included patients are presented in table 1.

Our study was based on a specially designed questionnaire containing questions about current disease, comorbidities, administered medicines and characteristics of pruritus. Similar questionnaires were successfully used by our group in other studies $[7,8]$. The current questionnaire focused on some clinical aspects of pruritus, such as how often it appeared during the course of the disease, what its intensity was at a particular time of the day, its location, feelings associated with pruritus and factors influencing the perception of pruritus. Severity of pruritus was assessed with the Visual Analogue Scale (VAS) and according to the Verbal Rating Scale (VRS) [9].

\section{Statistical analysis}

All data were analyzed statistically using Statistica 12.0 (StatSoft, Krakow).

\section{RESULTS}

\section{Clinical status}

The examined group of patients included $9(40.9 \%)$ subjects with hepatitis type B and 13 (59.1\%) with hepatitis type C. Duration of the hepatic disease varied between 3 and 22 years (mean: $10.5 \pm 5.5$ years). Three $(13.6 \%)$ patients had HIV coinfection. In addition, $15(68.2 \%)$ patients were diagnosed with liver cirrhosis during the course of viral hepatitis, and $1(4.5 \%)$ suffered from hepatocellular carcinoma (HCC). Twelve $(54.5 \%)$ patients had signs of liver decompensation: peripheral edemas $(n=9)$, coagulation disturbances $(n=7)$, icterus $(n=4)$, and ascites $(n=1)$. Furthermore, hepatomegaly was observed in $7(31.8 \%)$ patients and $7(31.8 \%)$ patients had esophageal varices with episodes of hemorrhages occurring in $6(27.3 \%)$ patients. Regarding the laboratory abnormalities, 7 (31.8\%) subjects had elevated serum alanine aminotransferase (ALT) and/or aspartate aminotransferase (AST) activity, 6 (27.3\%) had elevated $\gamma$-glutamyl transpeptidase (GGTP) activity and $6(27.3 \%)$ subjects had thrombocytopenia (table 2$)$. Regarding comorbidities, patients most frequently suffered from arterial hypertension (9 patients, $40.9 \%$ ) and diabetes type 2 (5 patients) (table 1). u których występował świąd. Świąd zgłosiło 22 (20\%) pacjentów (16 kobiet - 72,7\%, oraz 6 mężczyzn - 27,3\%; stosunek: $2,7: 1) \mathrm{w}$ wieku od 25 do 68 lat. Tylko te osoby włączono do dalszej analizy. Szczegółową charakterystykę pacjentów podano w tabeli 1 .

Badanie oparto na specjalnie opracowanej ankiecie zawierającej pytania dotyczące choroby podstawowej, schorzeń towarzyszących, stosowanych leków oraz charakterystyki świądu. Podobne kwestionariusze były już wcześniej z powodzeniem wykorzystywane przez nasz zespół w innych badaniach [7, 8]. Obecnie wykorzystany kwestionariusz skupiał się na zagadnieniach klinicznych dotyczących świądu, takich jak częstość występowania świądu w przebiegu choroby, jego nasilenie w poszczególnych porach dnia, lokalizacja, odczucia związane ze świądem oraz czynniki wpływające na jego postrzeganie. Nasilenie świądu oceniano w skali wzrokowo-analogowej (Visual Analogue Scale - VAS) oraz skali werbalnej (Verbal Rating Scale - VRS) [9].

\section{Analiza statystyczna}

Zgromadzone dane poddawano analizie statystycznej przy wykorzystaniu pakietu Statistica 12.0 (StatSoft, Kraków).

\section{WYNIKI}

\section{Ocena kliniczna}

Badana grupa obejmowała $9(40,9 \%)$ pacjentów z WZW typu B oraz 13 (59,1\%) pacjentów z WZW typu C. Czas trwania choroby wynosił się od 3 do 22 lat (średnia: 10,5 $\pm 5,5$ roku). U $3(13,6 \%)$ pacjentów występowało współzakażenie HIV. Ponadto u 15 (68,2\%) chorych w przebiegu WZW stwierdzono marskość wątroby, a u $1(4,5 \%)$ pacjenta raka wątrobowokomórkowego (hepatocellular carcinoma - HCC). U 12 (54,5\%) chorych występowały objawy dekompensacji czynności wątroby: obrzęki obwodowe $(n=9)$, zaburzenia krzepnięcia $(n=7)$, żółtaczka $(n=4)$ oraz wodobrzusze $(n=1)$. Inne stwierdzane objawy to hepatomegalia - u $7(31,8 \%)$ pacjentów oraz żylaki przełyku - u 7 (31,8\%) pacjentów, w tym u $6(27,3 \%)$ chorych występowały epizody krwawienia. Z odchyleń od normy w badaniach laboratoryjnych u 7 (31,8\%) pacjentów stwierdzono podwyższoną aktywność aminotransferazy alaninowej (ALT) i/lub aminotransferazy asparaginianowej (AST) w surowicy, u $6(27,3 \%)$ podwyższoną aktywność transpeptydazy $\gamma$-glutamylowej (GGTP), a u kolejnych 6 (27,3\%) trombocytopenię (tab. 2). Najczęstszymi chorobami współistniejącymi były: nadciśnienie tętnicze (9 pacjentów, $40,9 \%$ ) oraz cukrzyca typu 2 (5 pacjentów) (tab. 1). 
Table I. Detailed patient characteristics

Tabela I. Szczegółowa charakterystyka pacjentów

Patient characteristics/Charakterystyka pacjentów

$N(\%)$

Gender/Płeć:

\begin{tabular}{lc}
\hline Males/Mężczyźni & $6(27.3)$
\end{tabular}

$\begin{array}{ll}\text { Females/Kobiety } & 16(72.7)\end{array}$

Education/Wykształcenie:

Primary school/Podstawowe $3(13.6)$

Vocational/Zasadnicze zawodowe $8(36.4)$

High school/Średnie $\quad 7(31.8)$

UniversityMyższe $\quad 4(\mid 8.2)$

Place of living/Miejsce zamieszkania:

VillageNieś $2(9.1)$

Town $<100$ 000/Miasto $<100000$ mieszkańców 5 (22.6)

City $\geq 100$ 000/Miasto $\geq 100000$ mieszkańców

Viral hepatitis/Wirusowe zapalenie wątroby:

\begin{tabular}{lc}
\hline Type B/Typu B & $9(40.9)$ \\
\hline
\end{tabular}

Type C/Typu C $13(59.1)$

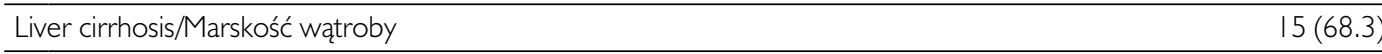

HIV coinfection/Współzakażenie HIV 3 (I3.6)

Concomitant diseases/Choroby wspótistniejące:

Hepatocellular carcinoma/Rak wątrobowokomórkowy I (4.5)

Arterial hypertension/Nadciśnienie tętnicze 10

Chronic heart insufficiency/Przewlekła niewydolność serca I (4.5)

Diabetes/Cukrzyca $5(22.6)$

Peptic ulcer disease/Choroba wrzodowa I (4.5)

Thyroid gland disease/Choroba gruczołu tarczowego 2 (9.1)

Glaucoma/Jaskra I (4.5)

Autoimmune diseases/Choroby autoimmunologiczne $2(9.1)$

Hypercholesterolemia/Hipercholesterolemia I (4.5)

Drugs taken by patients/Leki przyjmowane przez pacjentów:

\begin{tabular}{|c|c|}
\hline Antiviral drugs/Leki przeciwwirusowe & $7(31.8)$ \\
\hline Interferons/Interferony & $3(13.6)$ \\
\hline Beta-blockers/Leki $\beta$-adrenolityczne & $7(31.8)$ \\
\hline ACE inhibitors, sartans/Inhibitory ACE, sartany & $6(27.3)$ \\
\hline Diuretics/Diuretyki & $3(13.6)$ \\
\hline Calcium channel blockers/Inhibitory kanału wapniowego & $3(13.6)$ \\
\hline Metformin/Metformina & $3(13.6)$ \\
\hline Insulin/Insulina & $2(9.1)$ \\
\hline Acetylsalicylic acid/Kwas acetylosalicylowy & I (4.5) \\
\hline Proton pump inhibitors/Inhibitory pompy protonowej & $5(22.6)$ \\
\hline Ursodeoxycholic acid/Kwas ursodeoksycholowy & $5(22.6)$ \\
\hline Hepatoprotective drugs/Leki hepatoprotekcyjne & $6(27.3)$ \\
\hline Immunosuppressive drugs/Leki immunosupresyjne & $2(9.1)$ \\
\hline Other drugs*/Inne leki* & $4(18.2)$ \\
\hline
\end{tabular}

*Other drugs were taken in following order: travoprost, simvastatin, eplerenone, L-thyroxine.

*Inne przyjmowane leki wg częstości stosowania: trawoprost, simwastatyna, eplerenon, L-tyroksyna. 
Table 2. Clinical and laboratory disturbances related to liver disease

Tabela 2. Zaburzenia kliniczne i nieprawidłowości w badaniach laboratoryjnych związane z chorobą wątroby

\begin{tabular}{lc} 
Features of liver disease/Objawy choroby wątroby & N (\%) \\
\hline Edemas/Obrzęki & $9(40.9)$ \\
\hline Hepatomegaly/Hepatomegalia & $7(31.8)$ \\
\hline Coagulation disturbances/Zaburzenia krzepnięcia & $7(31.8)$ \\
\hline Esophageal varices/Żylaki przełyku & $7(31.8)$ \\
\hline Elevated serum ALT/AST activity/Podwyższona aktywność ALT/AST w surowicy & $7(31.8)$ \\
\hline Thrombocytopenia/Trombocytopenia & $6(27.3)$ \\
\hline Elevated serum GGTP activity/Podwyższona aktywność GGTP w surowicy & $6(27.3)$ \\
\hline Episodes of hemorrhages from esophageal varices/Epizody krwawienia z żylaków przełyku & $6(27.3)$ \\
\hline Icterus/Żółtaczka & $4(18.2)$ \\
\hline Ascites/Wodobrzusze & I (4.5) \\
\hline
\end{tabular}

ALT - alanine aminotransferase, AST - aspartate aminotransferase, GGTP - $\gamma$-glutamyl-transferase.

ALT - aminotransferaza alaninowa, AST - aminotransferaza asparaginianowa, GGTP - $\gamma$-glutamylotranspeptydaza.

\section{Characteristics of pruritus}

The severity of pruritus according to the VAS ranged from 2 to 6 points (mean: $3.7 \pm 1.8$ ). Nine $(40.9 \%)$ patients assessed pruritus according to the VRS as at least of moderate or severe intensity. The most common sites of pruritus were: trunk $(n=13$, $59.1 \%)$, upper limbs $(n=10,5.5 \%)$, thighs $(n=6$, $27.3 \%)$, neck $(n=6,27.3 \%)$ and head $(n=4,18.2 \%)$. Three (13.6\%) patients experienced itching on the entire body surface. Eighteen $(81.8 \%)$ patients reported that the itching caused irritation and distress and $6(27.3 \%)$ other patients complained about problems in concentration. A total of $13(59.1 \%)$ patients reported waking up during the night and 6 (27.3\%) indicated that pruritus caused difficulties in performing their jobs. A further $3(13.6 \%)$ patients reported that itching interrupted their usual daily activities, such as watching television or reading a newspaper. Everybody unanimously reported incidents of scratching, $10(45.5 \%)$ patients said that it only brought shortterm relief. The majority of patients $(n=16,72.7 \%)$ were not able to refrain from scratching.

Most commonly pruritus was described as pinching $(n=12,54.5 \%)$ and skin burning $(n=10,45.5 \%)$ sensations. Furthermore, patients mentioned a feeling of higher temperature of the skin $(n=8,36.4 \%)$, tickling $(n=7,31.8 \%)$ and stinging $(n=4,18.2 \%)$. Most frequently pruritus occurred in the evening or at night; in contrast, itching occurred rarely in the morning. The majority of participants $(n=14,63.6 \%)$ reported that pruritus occurs every day and single itching episodes last more than 10 minutes. Pruritus was most commonly worsened by heat $(n=14$; $63.6 \%)$, greasy creams/ointments $(n=5,22.7 \%)$ and clothes made of artificial fibers $(n=4,18.2 \%)$ and was improved by cold baths ( $n=11,50 \%$ ), emollients

\section{Charakterystyka świądu}

Nasilenie świądu w skali VAS wahało się od 2 do 6 pkt (średnia: $3,7 \pm 1,8)$. Dziewięciu $(40,9 \%)$ pacjentów oceniło nasilenie dolegliwości w skali VRS jako co najmniej umiarkowane lub ciężkie. Świąd był najczęściej umiejscowiony w obrębie tułowia $(n=13 ; 59,1 \%)$, kończyn górnych $(n=10 ; 5,5 \%)$, ud $(n=6 ; 27,3 \%)$, szyi $(n=6 ; 27,3 \%)$ i głowy $(n=4 ; 18,2 \%)$. U $3(13,6 \%)$ pacjentów występował świąd uogólniony obejmujący całą powierzchnię skóry. U 18 (81,8\%) pacjentów świąd wywoływał uczucie rozdrażnienia i niepokoju, a u kolejnych $6(27,3 \%)$ występowały problemy z koncentracją. U $13(59,1 \%)$ chorych świąd powodował wybudzenia w nocy, a $6(27,3 \%)$ chorym utrudniał wykonywanie pracy. Kolejnych $3(13,6 \%)$ pacjentów zgłosiło, że świąd zakłóca zwykłe codzienne czynności, takie jak oglądanie telewizji czy czytanie gazet. Wszyscy uczestnicy badania potwierdzili, że zdarzały się im incydenty drapania skóry, 10 (45,5\%) pacjentów oświadczyło, że drapanie przynosi jedynie krótkotrwałą ulgę. Większość chorych $(n=16 ; 72,7 \%)$ nie była $\mathrm{w}$ stanie powstrzymać się od drapania.

Świąd był najczęściej opisywany jako uczucie szczypania $(n=12 ; 54,5 \%)$ i pieczenia skóry $(n=10$; $45,5 \%)$. Pacjenci zgłaszali ponadto wrażenie rozgrzanej skóry $(n=8 ; 36,4 \%)$, łaskotania $(n=7 ; 31,8 \%)$ oraz kłucia $(n=4 ; 18,2 \%)$. Świąd najczęściej występował wieczorem lub w nocy, natomiast rzadko w godzinach porannych. U większości pacjentów $(n=14 ; 63,6 \%)$ pojawiał się codziennie, a pojedyncze epizody swędzenia skóry trwały ponad 10 minut. Świąd najczęściej zaostrzał się pod wpływem ciepła $(n=14 ; 63,6 \%)$, tłustych kremów lub maści $(n=5 ; 22,7 \%)$ oraz kontaktu skóry z odzieżą wykonaną ze sztucznych włókien $(n=4 ; 18,2 \%)$. Poprawę obserwowano natomiast po chłodnej kąpieli $(n=11 ; 50 \%)$, zastosowaniu emo- 
$(n=4,18.2 \%)$ and menthol preparations $(n=2,9.1 \%)$. No significant differences were noted between HBV and HCV patients (data not shown).

\section{DISCUSSION}

Pruritus is a frequent phenomenon in patients with liver diseases, especially in those suffering from primary biliary cholangitis and primary sclerosing cholangitis. However, data about its prevalence in patients suffering from chronic viral hepatitis are limited [10]. To fill this gap, we performed a study to elucidate the prevalence and clinical characteristics of pruritus in patients infected with $\mathrm{HBV}$ and/or $\mathrm{HCV}$. Based on our results it can be concluded that about $1 / 5$ of patients with chronic viral hepatitis suffer from pruritus. No significant difference between patients with $\mathrm{HBV}$ and $\mathrm{HCV}$ infection regarding the pruritus prevalence, severity and characteristics was observed, which is slightly contradictory to previous findings that pruritus might be more common in patients with $\mathrm{HCV}[5,10]$. However, it should be underlined that in most of our cases pruritus was related to an advanced stage of liver disease, usually to situations with signs of marked liver damage or even liver cirrhosis, suggesting that not viral infection per se, but rather the consequences of chronic inflammation and liver remodeling, could be linked with pruritus in subjects with viral hepatitis. However, we cannot exclude the possibility that patients with advanced liver disease are probably more willing to seek medical consultation, and this fact might influence the observed high prevalence of liver cirrhosis among pruritic subjects.

Although pruritus in viral hepatitis is not so prevalent as in other liver pathologies with cholestasis, it cannot be downplayed by clinicians, as patients infected with HBV and HCV truly suffer because of the itching. Pruritus often caused irritation, waking up during the night or prevented patients from working, limiting their productivity. The majority of the group with pruritus could not resist scratching and had secondary skin changes, which might increase the risk of secondary infections. These facts indicate the importance of the problem and the need for effective antipruritic management.

The pathogenesis of cholestatic or liver-disease associated pruritus remains unknown, but recent studies provided new data which might improve our understanding of this debilitating symptom. Several lines of evidence suggested that a circulating pruritogen is responsible for pruritus, but the identification of the molecule has yet to be definitively identified [11]. In the past a number of possible mediators were postulated, including endogenous opioids, serotonin, progesterone metabolites, or bile acids, and still lientów $(n=4 ; 18,2 \%)$ oraz preparatów mentolowych $(n=2 ; 9,1 \%)$. Nie odnotowano znamiennych różnic między pacjentami z HBV i HCV (dane nieuwzględnione).

\section{OMÓWIENIE}

Świąd jest częstym zjawiskiem u pacjentów ze schorzeniami wątroby, zwłaszcza z pierwotną marskością żółciową wątroby i pierwotnym stwardniającym zapaleniem dróg żółciowych. Dostępne są jednak tylko ograniczone dane dotyczące częstości występowania tego objawu u pacjentów z przewlekłym WZW [10]. Aby wypełnić tę lukę, przeprowadziliśmy badanie analizujące częstość występowania i obraz kliniczny świądu u pacjentów zakażonych wirusem HBV i/lub HCV. Na podstawie uzyskanych wyników można stwierdzić, że około $20 \%$ pacjentów z przewlekłym zapaleniem wątroby odczuwa świąd. Nie odnotowano istotnej różnicy między chorymi zakażonymi HBV i HCV pod względem występowania świądu, jego nasilenia lub obrazu klinicznego. Obserwacja nie jest zgodna z wcześniej uzyskanymi wynikami, które wskazują na częstsze występowanie świądu u pacjentów zakażonych HCV $[5,10]$. Należy jednak podkreślić, że w większości przypadków analizowanych w naszej pracy świąd wiązał się z zaawansowanym stadium choroby wątroby. U pacjentów występowały objawy znacznego uszkodzenia tego narządu, a nawet marskości, co może sugerować, że u pacjentów z WZW świąd może być raczej skutkiem przewlekłego stanu zapalnego i przebudowy wątroby niż samej infekcji wirusowej. Nie można jednak wykluczyć, że pacjenci z zaawansowanym schorzeniem wątroby częściej zgłaszają się do lekarza, co następnie może wpływać na obserwowaną dużą częstość występowania marskości wątroby u chorych odczuwających świąd.

Choć świąd w przebiegu WZW nie jest tak częsty jak w innych zaburzeniach wątroby, którym towarzyszy zastój żółci, klinicyści nie powinni lekceważyć tego objawu ze względu na dużą uciążliwość dla pacjentów z zakażeniem HBV i HCV. Świąd często wywołuje rozdrażnienie, powoduje wybudzenia w nocy lub uniemożliwia pracę, ograniczając produktywność. Większość pacjentów z analizowanej grupy nie mogła powstrzymać się od drapania. Prowadziło to do powstawania wtórnych zmian skórnych, a także do zwiększonego ryzyka wystąpienia wtórnych zakażeń. Pokazuje to, jak istotnym problemem jest świąd, oraz wskazuje na konieczność prowadzenia u chorych skutecznego postępowania przeciwświądowego.

Patogeneza świądu związanego z cholestazą lub chorobą wątroby nie została dotąd wyjaśniona, jednak niedawne badania dostarczyły nowych danych, które mogą się przyczynić do lepszego poznania tego uciążliwego objawu. Kilka doniesień wskazuje, że za rozwój świądu odpowiada krążący pruritogen, jednak cząsteczki tej nie udało się dotychczas jednoznacznie zidentyfikować [11]. W przeszłości wskazano kilka po- 
some of these substances are believed to be relevant. However, more recent data suggested that autotaxin (ATX), an enzyme involved in lysophosphatidic acid (LPA) production by conversion of lysophosphatidylcholine (LPC) to LPA, might be a key player in cholestatic pruritus [11-14]. It was observed that plasma ATX activity is strongly associated with pruritus in primary sclerosing cholangitis and that LPA might evoke pruritus in mice when injected intradermally [14]. These observations suggest that ATX blockade might be a good candidate for effective antipruritic therapies, but this hypothesis need to be verified in future clinical studies.

Treatment of cholestatic pruritus remains a challenge. Usually topical and systemic therapies can offer only short-term relief and most are associated with complicated adverse effects, particularly in patients with chronic HCV infection [5]. Among available treatment options, rifampicin (150-600 mg/day) was best tested and was shown to be significantly more effective than other drugs [15-17]. However, many authors suggest using resins first (e.g. colestyramine 4-16 g/day), as it is probably a safer treatment option $[18,19]$. If both treatment options fail, $\mu$-opioid receptor antagonists (e.g. naltrexone $50 \mathrm{mg} /$ day) or selective serotonin re-uptake inhibitors (e.g. paroxetine 10-40 mg/day, sertraline 75-100 mg/day) are worth trying, as they may also provide some pruritus relief in selected subjects with cholestatic itch $[18,19]$. Recent data also indicated that $\mathrm{K}-$ opioid receptor agonists may be effective; however, nalfurafine, a potent $\mathrm{K}$-opioid receptor agonist, is currently available only in Japan [20].

The current study has several limitations that should be taken into account when interpreting our results. The cross-sectional design of the study enabled us to identify patients with pruritus at certain moments of the liver disease. Longitudinal studies should be able to better assess the incidence of pruritus over time and the relationship with various stage of liver damage. Furthermore, the analyzed group was small and came from a single center. The next studies should include more patients and be performed in various centers dealing with $\mathrm{HBV} / \mathrm{HCV}$ patients to limit the regional differences. Lack of a control group is another limitation which prevented us demonstrating peculiarities of pruritus in HBV/ HCV patients. Nevertheless, we hope that despite these limitations our data are interesting and valid, as it is one of the first studies dealing with this topic.

\section{CONCLUSIONS}

It seems that about $1 / 5$ of patients with chronic viral hepatitis suffer from pruritus, which in some cases might be associated with marked liver damage or liv- tencjalnych mediatorów świądu, takich jak endogenne opioidy, serotonina, metabolity progesteronu i kwasy żółciowe. Współcześnie również uważa się, że niektóre z tych substancji odgrywają pewną rolę w rozwoju tego objawu. Nowsze dane sugerują jednak, że czynnikiem warunkującym występowanie świądu cholestatycznego może być autotaksyna (ATX), enzym uczestniczący w produkcji kwasu lizofosfatydowego (LPA) w procesie przemiany lizofosfatydylocholiny (LPC) w LPA [11-14]. Zaobserwowano, że aktywność ATX w osoczu ściśle wiąże się ze świądem w pierwotnym stwardniającym zapaleniu dróg żółciowych, a LPA może wywoływać świąd u myszy po wstrzyknięciu śródskórnym [14]. Obserwacje te wskazują, że blokada ATX może być podstawą do opracowania skutecznych terapii przeciwświądowych, jednak hipoteza ta wymaga weryfikacji w badaniach klinicznych.

Terapia świądu cholestatycznego nadal stanowi wyzwanie. Leczenie miejscowe i ogólnoustrojowe zazwyczaj przynosi jedynie krótkotrwałą ulgę, a przy tym wiąże się ze złożonymi działaniami niepożądanymi, zwłaszcza u pacjentów z przewlekłym zakażeniem HCV [5]. Spośród dostępnych opcji leczniczych najdokładniej przebadano ryfampicynę (150-600 mg/dobę), wykazując jej wyższą skuteczność od pozostałych leków [15-17]. Wielu autorów postuluje jednak wdrożenie w pierwszej kolejności leczenia związkami z grupy żywic (np. kolestyraminą w dawce 4-16 g/dobę), ponieważ są one prawdopodobnie bezpieczniejsze $[18,19]$. W razie niepowodzenia obu tych metod warto zastosować leki z grupy antagonistów receptora opioidowego $\mu$ (np. naltrekson $50 \mathrm{mg} /$ dobę) lub selektywnych inhibitorów zwrotnego wychwytu serotoniny (np. paroksetynę w dawce $10-40 \mathrm{mg} /$ dobę, sertralinę w dawce $75-100 \mathrm{mg} /$ dobę). Leki te mogą również przynosić pewną ulgę niektórym pacjentom ze świądem cholestatycznym $[18,19]$. Ostatnie dane wskazują na potencjalną skuteczność agonistów receptora opioidowego $\mathrm{k}$, jednak nalfurafina, silny agonista receptora opioidowego $\mathrm{K}$, jest obecnie dostępna wyłącznie na rynku japońskim [20].

Przeprowadzona analiza ma pewne ograniczenia, które należy uwzględnić przy interpretacji wyników. Przekrojowy schemat badania umożliwił zidentyfikowanie pacjentów odczuwających świąd w pewnym punkcie czasowym w przebiegu schorzenia wątroby. Przy ocenie występowania świądu w miarę upływu czasu oraz zależności między świądem a poszczególnymi stadiami choroby wątroby bardziej przydatny byłby schemat podłużny. Analizę wykonano w niewielkiej grupie chorych z jednego ośrodka. W kolejnych badaniach należałoby uwzględnić większą liczbę osób, a także kilka różnych ośrodków zajmujących się leczeniem pacjentów z HBV lub HCV, aby ograniczyć oddziaływanie różnic regionalnych. Innym ograniczeniem jest brak grupy kontrolnej, który uniemożliwił opisanie swoistego obrazu świądu u pacjentów z HBV lub HCV. Niemniej jest to jedna z pierwszych prac na 
er cirrhosis, suggesting that not viral infection per se, but rather the consequences of chronic inflammation and liver remodeling, could be linked with pruritus in subjects with viral hepatitis. Treatment of cholestatic pruritus remains a challenge, but better understanding of its pathogenesis creates a hope that effective antipruritic therapies will appear in the near future.

\section{ACKNOWLEDGMENTS}

We would like to thank the "Gwiazda Nadziei" ("Star of Hope") Foundation, which supported our study. We are also grateful to all patients who agreed to participate in this study and completed the questionnaire. Many thanks also to Magda Stępniewska, who contributed to the development of the initial version of the questionnaire.

Anna Biernacka and Dawid Niżyński contributed equally to this work.

\section{CONFLICT OF INTEREST}

The authors declare no conflict of interest. ten temat i mamy nadzieję, że mimo ograniczeń uzyskane dane są ciekawe i wiarygodne.

\section{WNIOSKI}

Świąd występuje u około $20 \%$ pacjentów z przewlekłym WZW. W niektórych przypadkach może być związany ze znacznym uszkodzeniem lub marskością wątroby. Obserwacja ta wskazuje, że nie samo zakażenie wirusem, ale raczej skutki przewlekłego stanu zapalnego i przebudowy wątroby mogą warunkować rozwój świądu u pacjentów z WZW. Leczenie świądu cholestatycznego nadal pozostaje wyzwaniem, jednak lepsze poznanie patogenezy tego objawu daje nadzieję na opracowanie skutecznych leków przeciwświądowych w niedalekiej przyszłości.

\section{PODZIĘKOWANIA}

Dziękujemy Fundacji „Gwiazda Nadziei” za wsparcie badania. Podziękowania kierujemy również do pacjentów, którzy zgodzili się na udział w badaniu i wypełnili ankietę. Serdecznie dziękujemy Magdzie Stępniewskiej za wkład w opracowanie początkowej wersji kwestionariusza.

Anna Biernacka i Dawid Niżyński wnieśli równy wkład merytoryczny w opracowanie artykułu.

\section{KONFLIKT INTERESÓW}

Autorzy nie zgłaszają konfliktu interesów.

\section{References}

Piśmiennictwo

1. Szepietowski J., Reich A.: Świąd. Patomechanizm, klinika, leczenie. Wydawnictwa Medyczne Termedia, Poznań, 2010.

2. Weisshaar E., Dalgard F.: Epidemiology of itch: adding to the burden of skin morbidity. Acta Derm Venereol 2009, 89, 339350 .

3. Bergasa N.V.: Pruritus and fatigue in primary biliary cirrhosis. Clin Liver Dis 2003, 7, 879-900.

4. Tengan F.M., Levy-Neto M., Miziara I.D., Dantas B.P., Maragno L.: Extrahepatic manifestations of chronic hepatitis C infection: a consecutive study in Brazilian patients. Braz J Infect Dis 2017, 21, 203-204.

5. Alhmada Y., Selimovic D., Murad F., Hassan S.L., Haikel Y., Megahed M., et al.: Hepatitis C virus-associated pruritus: etiopathogenesis and therapeutic strategies. World J Gastroenterol 2017, 23, 743-750.

6. Reich A., Welz-Kubiak K., Rams L.: Apprehension of the disease by patients suffering from psoriasis. Postep Dermatol Alergol 2014, 31, 289-293.

7. Welz-Kubiak K., Reich A., Szepietowski J.C.: Clinical aspects of itch in lichen planus. Acta Derm Venereol 2017, 97, 505-508.

8. Chrostowska-Plak D., Salomon J., Reich A., Szepietowski J.C.: Clinical aspects of itch in adult atopic dermatitis patients. Acta Derm Venereol 2009, 89, 379-383.

9. Reich A., Riepe C., Anastasiadou Z., Mędrek K., Augustin M., Szepietowski J.C., et al.: Itch Assessment with Visual Analogue Scale and Numerical Rating Scale: determination of minimal clinically important difference in chronic itch. Acta Derm Venereol 2016, 96, 978-980.

10. Chia S.C., Bergasa N.V., Kleiner D.E., Goodman Z., Hoofnagle J.H., Di Bisceglie A.M.: Pruritus as a presenting symptom of chronic hepatitis C. Dig Dis Sci 1998, 43, 2177-2183.

11. Sun Y., Zhang W., Evans J.F., Floreani A., Zou Z., Nishio Y., et al.: Autotaxin, pruritus and primary biliary cholangitis (PBC). Autoimmun Rev 2016, 15, 795-800.

12. Kremer A.E., Namer B., Bolier R., Fischer M.J., Oude Elferink R.P., Beuers U.: Pathogenesis and management of pruritus in PBC and PSC. Dig Dis 2015, 33 Suppl 2, 164-175. 
13. Kremer A.E., Martens J.J., Kulik W., Ruëff F., Kuiper E.M., van Buuren H.R., et al.: Lysophosphatidic acid is a potential mediator of cholestatic pruritus. Gastroenterology 2010, 139, 1008-1018, 1018.e1.

14. Oude Elferink R.P., Kremer A.E., Martens J.J., Beuers U.H.: The molecular mechanism of cholestatic pruritus. Dig Dis 2011, 29, 66-71.

15. Ghent C.N., Carruthers S.G.: Treatment of pruritus in primary biliary cirrhosis with rifampin. Results of a double-blind, crossover, randomized trial. Gastroenterology 1988, 94, 488-493.

16. Cynamon H.A., Andres J.M., Iafrate R.P.: Rifampin relieves pruritus in children with cholestatic liver disease. Gastroentero$\log$ 1990, 98, 1013-1016.

17. Yerushalmi B., Sokol R.J., Narkewicz M.R., Smith D., Karrer F.M.: Use of rifampin for severe pruritus in children with chronic cholestasis. J Pediatr Gastroenterol Nutr 1999, 29, 442-447.

18. Hegade V.S., Kendrick S.F., Jones D.E.: Drug treatment of pruritus in liver diseases. Clin Med (Lond) 2015, 15, $351-357$.

19. Reich A., Ständer S., Szepietowski J.C.: Pruritus in the elderly. Clin Dermatol 2011, 29, 15-23.

20. Akuta N., Kumada H., Fujiyama S., Kawamura Y., Sezaki H., Hosaka T., et al.: Predictors of pruritus in patients with chronic liver disease and usefulness of nalfurafine hydrochloride. Hepatol Res 2018, 48, 45-50.

Received: 2.11.2017

Accepted: 6.02 .2018

Otrzymano: $2.11 .2017 \mathrm{r}$

Zaakceptowano: $6.02 .2018 \mathrm{r}$ 